\title{
Perinatal outcome of multiple pregnancy
}

\author{
Susithra Saravanan*, Malarvizhi Loganathan
}

Department of Obstetrics and Gynecology, Government Dharmapuri Medical College and Hospital, Dharmapuri, Tamil Nadu, India

Received: 23 March 2017

Revised: 25 April 2017

Accepted: 28 April 2017

\section{*Correspondence:}

Dr. Susithra Saravanan,

E-mail: susi_saravanan@yahoo.co.in

Copyright: (c) the author(s), publisher and licensee Medip Academy. This is an open-access article distributed under the terms of the Creative Commons Attribution Non-Commercial License, which permits unrestricted non-commercial use, distribution, and reproduction in any medium, provided the original work is properly cited.

\section{ABSTRACT}

Background: Multifetal gestation in addition to perinatal mortality and morbidity, attributable to preterm delivery they are more vulnerable to unique complications such as, structural malformations and twin- twin transfusion syndrome so that still birth rates are also appreciably increased. The incidence of multifetal gestation following conventional gonadtropin therapy is $16-40 \%$ with $75 \%$ being twins, with super ovulation it is $25-30 \%$. The incidence of twins and triplets with embryo transfer $22-24 \%$ and $26 \%$ respectively.

Methods: The clinical material taken from institute of Obstetrics and Gynaecology, Egmore Maternity, Chennai. Material for this study consists of 100 multiple pregnancies from May 2001 to April 2002. During this study period 19,617 patients admitted for delivery. There were 99 seats of twins and 1 Triplets.

Results: During the period of 1 year, 150 cases were analyzed. During the period 148 cases 2 cases of tripelets studied, no cases of quadruplets were reported during this period.

Conclusions: Multifetal gestation is one of the high-risk pregnancies. Hence women with multifetal gestation should ideally receive antenatal care in special twin clinics to meet their special needs. The multi-disciplinary team should be lead by an obstetrician, should include midwives, USG, Neonatologists, social workers and anesthetists. Women followed in twin clinic had significant improvement in women outcome which includes increased mean birth weight, decreased low birth weight and low ICU admissions.

Keywords: Low birth weight, Multi fetal gestation, Multiple pregnancy, Perinatal outcome, Post-partum haemorrhage, Twins

\section{INTRODUCTION}

Multifetal gestation is one of the few topics in obstetrics, which have stimulated more interest and generated more literature than any others. Serious efforts have been made to unify all kinds of contributions on twins into a new branch of science named Gamellology.

Multifetal gestation has gained interest amoung the obstetrician because its extraordinary increase is a public health concerns, as these infants are less likely to survive and more likely to suffer lifelong disability due to preterm delivery. In addition to perinatal mortality and morbidity, attributable to preterm delivery they are more vulnerable to unique complications such as, structural malformations and twin- twin transfusion syndrome so that still birthrates are also appreciably increased. ${ }^{1,2}$

Also, according to conde-agudelo and co-workers (2000) found a twofold significant risk of pre-eclampsia, PPH and maternal death in a study of over 15,000 pregnancies. Currently, multifetal gestation accounts for $3 \%$ of all pregnancies (ACOG 1998). An important factor increasing the incidence of multifetal gestation has been the 
development of ovulation induction in infertile couples. The incidence of multifetal gestation following conventional gonadtropin theraphy is $16-40 \%$ with $75 \%$ being twins, with super ovulation it is $25-30 \%$. The incidence of twins and triplets with embryo transfer 22$24 \%$ and $26 \%$ respectively. 3,4

There are two types of twining

- Dizygotic due to fertilization of two separate ova.

- Monozygotic from division of one fertilized ovum into two separate embryos.

- Tripletes are derived from three separate ova from two ova, one of which gives rise to monozygotic twins or very rarely forms single ovum,

Success in managing multifetal gestation depends on serial fetal monitoring, supportive psychological counseling clinical skill and timely intervention. ${ }^{5,6}$

Aims and objects of this clinical study are perinatal mortality and morbidity, pregnancy outcome in 100 cases of multiple pregnancy, to study the influence of pregnancy complications (like anemia, pregnancy induced hypertension, premature rupture of membrane, atonic PPH), method of delivery of foetuses and birth weight of each foetus and to determine the cause of perinatal death in multiple pregnancy.

\section{METHODS}

The clinical material taken from institute of Obstetrics and Gynaecology, Egmore Maternity, Chennai. Material for this study consists of 100 multiple pregnancies from May 2001 to April 2002. During this study period 19,617 patients admitted for delivery. There were 99 seats of twins and 1 Triplets.

\section{Inclusion criteria}

- Women with over distended uterus
- Women with multifetal parts

- Women who are diagnosed elsewhere as multifetal gestation

- Women with family history of multifetal gestation.

\section{Exclusion criteria}

- Women with uncertained LMP

- Women with uterus less than period of amenorrhoea

- Women with bed obstetric history.

At the antenatal visits, careful history was taken from all women regarding the period of amenorrhoea, nausea, vomiting, swelling of extremities, swelling over the abdomen (PIH), breathlessness and easy fatiguability, UTI, pressure symptoms, previous obstetrics history, previous multiple pregnancy, ovulation induction, family history, multiple pregnancy and events in each trimester.

Then a thorough general and obstetric examination was done to look for evidence of anemia, PIH, presentation of fetuses, fetal parts and fetal heart and ultrasonogram to confirm the diagnosis. Hb, Urine albumin \% blood grouping done for all cases.

When patient was admitted with labour pains, intrapartum, complications like PROM and abruption, the method of delivery of fetuses, condition of the babies at birth, conditions of the mother and baby subsequently till discharge are noted. Placenta was examined thoroughly for the number and chorio-amnion relationship.

\section{RESULTS}

During the period of 1 year, 150 cases were analyzed. During the period 148 cases 2 cases of tripelets studied, no cases of quadruplets were reported during this period.

The incidence of multiple pregnancies at IOG during the study period (May 2001 to April 2002) is 7.6/1000 births.

Table 1: Incidence of multiple pregnancy at IOG.

\begin{tabular}{|llllll|}
\hline Year & $\begin{array}{l}\text { Total no. of } \\
\text { delivery }\end{array}$ & No. of twins & No. of tripelets & Total no. of multiple pregnancy & Tncidence \\
\hline 2000 to 2001 & 18000 & 150 & 5 & 155 & 8.6 \\
\hline Study period & 19617 & 148 & 2 & 150 & 7.6 \\
\hline
\end{tabular}

In this study, the incidence of multiple pregnancy is common in age group of 20-24 years about 56\% (Table 2).

Incidence of PROM is $13.3 \%$ in this study group compared to $10 \%$ in general population. Incidence of atonic PPH is $6.7 \%$ in this study group compared to $5.2 \%$ in general population. PNMR in multifetal gestation 1s $119 / 1000$ births in this study series. This is 3 times higher than

PNMR in general population, which is $41 / 1000$ births in IOG for this study period. The II and the subsequent fetuses are at increased risk than the I one. In a Cohort study by smith G.C.S at Scotland (1992-97), it has been 
reported that twin born at term is at higher risk that the first twin probably due to,

- Intrapartum hypoxia.

- Mechanical causes like cord prolapsed.

Table 2: Age incidence.

\begin{tabular}{|llll|}
\hline Age (years) & No. & Percent & $\begin{array}{l}\text { Multicentric } \\
\text { prospective } \\
\text { twins study }\end{array}$ \\
\hline$<20$ & 10 & 7 & $2.8 \%$ \\
\hline $20-24$ & 85 & 56 & $39.9 \%$ \\
\hline $25-29$ & 42 & 28 & $46.9 \%$ \\
\hline $30-34$ & 12 & 8 & $7 \%$ \\
\hline $35-39$ & 1 & 1 & $2.7 \%$ \\
\hline
\end{tabular}

In this study series of the 20 perinatal deaths of II twin 7 of them where at 37 completed weeks, whereas of the 15 perinatal deaths of I twin none of them were at or above completed weeks.

Perinatal loss is higher in cases admitted during labour. Perinatal mortality is highest if maternal age is less than 20 years. In this study PNMR is lowest in G2 and G3. Perinatal death is very clearly related to prematurity and its attendant complication. In this study, PNM is highest in assisted breech delivery, the rate being 217/1000.

Table 3: Pregnancy complications in multiple pregnancy.

\begin{tabular}{|llll|}
\hline $\begin{array}{l}\text { Pregnancy } \\
\text { complications }\end{array}$ & No & Percentage & $\begin{array}{l}\text { Mumbai } \\
\text { study }\end{array}$ \\
\hline Anaemia & 50 & 33.3 & $36 \%$ \\
\hline PIH & 30 & 20 & $23.3 \%$ \\
\hline PROM & 20 & 13.3 & -- \\
\hline Atonic PPH & 10 & 6.7 & -- \\
\hline
\end{tabular}

Table 4: Perinatal mortality and birth order in multiple pregnancy.

\begin{tabular}{|lllll|} 
& I & II & III & Total \\
\hline Discharged alive & 135 & 130 & 1 & 266 \\
\hline Perinatal loss & 15 & 20 & 1 & 36 \\
\hline PNMR & $100 / 1000$ & $133 / 1000$ & $500 / 1000$ & $119 / 1000$ \\
\hline
\end{tabular}

Table 5: Perinatal mortality and time of admission in multiple pregnancy.

\begin{tabular}{|lll|l|}
\hline Admissions & No. & $\begin{array}{l}\text { Perinatal } \\
\text { loss }\end{array}$ & PNMR \\
\hline Before labour & 95 & 3 & $37 / 1000$ \\
\hline At labour & 55 & 25 & $454.5 / 1000$ \\
\hline
\end{tabular}

Table 6: Perinatal mortality and maternal age.

\begin{tabular}{|llll|}
\hline $\begin{array}{l}\text { Age } \\
\text { (years) }\end{array}$ & $\begin{array}{l}\text { No. of } \\
\text { pregnancy }\end{array}$ & $\begin{array}{l}\text { No. of } \\
\text { perinatal loss }\end{array}$ & PNMIR \\
\hline$<20$ & 10 & 4 & 200 \\
\hline $20-24$ & 90 & 14 & 78 \\
\hline $25-29$ & 41 & 7 & 85 \\
\hline $30-34$ & 8 & 3 & 188 \\
\hline $35-39$ & 1 & - & - \\
\hline
\end{tabular}

\section{DISCUSSION}

\section{Perinatal mortality}

Perinatal mortality includes all still births and neonatal deaths up to 7 days after birth/ 1000 births. PNMR in multiple pregnancy is 4 times increased than in singleton, with rates of 15-31\% (Revenis M.E. 1994, Neonatology and pathophysiology and management of new born. ${ }^{7}$
Table 7: Perinatal mortality and parity.

\begin{tabular}{|ll|ll|}
\hline Parity & $\begin{array}{l}\text { No. of } \\
\text { pregnancy }\end{array}$ & $\begin{array}{l}\text { No. of } \\
\text { perinatal loss }\end{array}$ & PNMR \\
\hline G1 & 50 & 17 & $170 / 1000$ \\
\hline G2 & 65 & 8 & $62 / 1000$ \\
\hline G3 & 20 & 1 & $25 / 1000$ \\
\hline G4 & 9 & 2 & $111 / 1000$ \\
\hline G5 & 5 & - & - \\
\hline G6 & 1 & - & - \\
\hline
\end{tabular}

The increased frequency of prematurity, preeclampsia, hydramnios, PIH, abruption and cord prolapse contribute to preinatal mortality. In this study series.

- $\quad$ PNMR of I baby-100/1000

- $\quad$ PNMR of II baby $-133 / 1000$

- PNMR of III baby $-155 / 1000$

- Total PNMR - 119/1000

Perinatal mortality of II twin is more than that of I twin. This is related to

- Time interval after delivery of I baby

- Higher incidence of breech

- Operative deliveries associated with II of the twin

- Cord prolapsed 
Fetal risks of delayed time interval are,

- Fetal distress

- Sepsis

- Intrauterine demise

Table 8: Perinatal mortality and gestational age at birth.

\begin{tabular}{|llll|}
\hline $\begin{array}{l}\text { GA in } \\
\text { weeks }\end{array}$ & $\begin{array}{l}\text { No. of } \\
\text { pregnancy }\end{array}$ & $\begin{array}{l}\text { No. of } \\
\text { perinatal loss }\end{array}$ & PNMIR \\
\hline $28-30$ & 6 & 4 & $667 / 1000$ \\
\hline $31-33$ & 11 & 7 & $636 / 1000$ \\
\hline $34-36$ & 74 & 12 & $162 / 1000$ \\
\hline $\begin{array}{l}37 \text { and } \\
\text { above }\end{array}$ & 59 & 5 & $85 / 1000$ \\
\hline
\end{tabular}

\section{Perinatal mortality and birth weight}

Up to 30 weeks of gestation the growth rate is similar in twins and singleton. After 30 weeks, the singleton fetus has accelerated, exponential growth while the twin fetuses have a more linear rate of growth. ${ }^{8}$

Multifetal gestation account for $17 \%$ IUGR with higher mortality rates for affected infants. In this study series PNMR for birth weight $1-1.5 \mathrm{~kg}$ is $388 / 1000$; most of the babies above $1.5 \mathrm{~kg}$ survived and were discharged well. ${ }^{9}$ Total number of deliveries at IOG from May 2001 to April 2002 was 19,617 . The total Number of multiple births was 177 in which 3 were triplets and 174 were twins, out of which 150 cases were taken for this study, which comprises of 148 twins and 2 triplets.

Table 9: Perinatal mortality and mode of delivery.

\begin{tabular}{|lllllll|l|}
\hline & I & & II & \multicolumn{3}{c|}{ III } & PNMR \\
\hline Mode of delivery & No. & PNL & No. & PNL & No. & PNL & $103 / 1000$ \\
\hline Labour natural & 96 & 9 & 79 & 9 & 1 & 0 & $217 / 1000$ \\
\hline Assisted breech delivery & 26 & 7 & 43 & 7 & 1 & 1 & - \\
\hline Forceps & 4 & 0 & 0 & 0 & 0 & 0 & - \\
\hline LSCS & 24 & 3 & 28 & 0 & 0 & 0 & - \\
\hline
\end{tabular}

Multiple pregnancy was common in the age group of 2024 years and in G2. Prenatal diagnosis plays an important role in the perinatal outcome. In this study series $96 \%$ were confirmed by USG. In this study series, the incidence of Anaemia 33.3\%, PIH 20\%, PROM 13.3\%, Atonic PPH $6.7 \%$.

Perinatal mortality for multifetal gestation is about 3 times higher than that of singleton pregnancies in this study series.

The II baby fare less well than 1 baby

- PNMR of I baby is $100 / 1000$

- PNMR of II baby is $133 / 1000$

- $\quad$ PNMR of III baby is 500/1000

- Total PNMR is $119 / 1000$

The time of delivery of II twin also plays an important role the longer the interval between the delivery of twins, the greater the perinatal mortality. ${ }^{10}$ The PNMR is higher is MZ babies when compared to DZ babies. PNMR in MZ310/1000 and PNMR in DZ-105/1000.

Vertex presentation is the most common and had a better perinatal outcome then others. Breech presentation had a worst outcome.

- $\quad$ PNMR is LSCS 58/1000

\section{- $\quad$ PNMR in ABD 217/1000 \\ - $\quad$ PNMR in LN 103/1000}

Birth weight of babies is most important which determines the perinatal outcome. In this studies series

- PNMR of babies between 1-1.5 is $388 / 1000$

- $\quad$ PNMR of babies between 1.5- 2.0 is $43 / 1000$

Most common cause of Perinatal mortality and morbidity in Multifetal gestation was prematurity. The fetal loss II twin is lightly more than I twin, mainly due to asphyxia, low birth weight and RDS. The use of ovulation inducing agents in only 3 (2.2\%)cases could suggest multiple pregnancy due to child bearing at older maternal ages and the tendency to deliver more children. ${ }^{11,12}$

The average gestation at which twin deliveries occur is 35 weeks and for triplets it is 33 weeks. Preterm delivery occurs in about one half of the twins and accounts for 10$12 \%$ of all preterm births. ${ }^{13-15}$

\section{CONCLUSION}

Perinatal/neonatal mortality and morbidity are significantly higher in multifetal gestation than in singleton pregnancy. Patient with a multiple delivery should be clinically managed as high risk pregnancy. USG evaluation is the single most important diagnostic test in 
multifetal gestation. The incidence of congential malformation is 2-3 times higher in fetuses of multifetal gestation, when compared with those of singleton gestation. All patients with multifetal gestation, should have thorough I and II trimester USG examines to assess for the chorionicity, amnionicity, individual fetal growth and congential malformation. TTT is a serious complication in MZ with an increased FMR. Prophylactic circlage or tocolytics do not have any proven advantage in the management of multifetal gestation.

Marked divergence from singleton growth among both twins and triplets appear to begin at approximately 28 weeks of gestation and then to widen progressively. Delivery must be at a level III hospital. As a general rule mode of delivery should be vaginal when both twins present as vertex and CS when I twin is NVx, for triplets the safest mode of delivery is CS. Active management of II twin with an optional time interval of 15 minutes improves perinatal outcome. Immediate neonatal intensive xcare contributes to improve perinatal and neonatal outcome.

Funding: No funding sources Conflict of interest: None declared

Ethical approval: The study was approved by the Institutional Ethics Committee

\section{REFERENCES}

1. Burnett AF. Clinical $\mathrm{O}$ and G: a problem based approach, Blackwell Scurvier Publishes, India; 2001.

2. Boklage CE. Multiple pregnancy, epidemiology, gestation and PM outcome. New York. The Parthenon Publishing Group. 1995:41-50.

3. Berch T, Ericson A, Hillensjo T. Deliveries and children born after IVF treatment is Sweden 19821995: a complete cohort study. Lancet. 1999;354:1579-85.
4. Elsner CW, Tucker MJ, Sweitzer CL. Multiple pregnancy rate and embryo number and transfer during invitro fertilization. Am J Obstet Gyncol. 1997; 177:50-357.

5. Gandhi JA, Maidman JE. Fetal testing in multiple pregnancy. Isreal J OBG. 1997;8:16-23.

6. Benirschke K. Twin Placenta in PNM, my state. J Med. 1961;61:1499-1508.

7. Revenis ME. Neonatology and pathophysiology and management of new born. 1994.

8. Antsaklis A, Daskalakis G, Papageorgiou I, Aravantinos D. Conservative treatment after miscarriage of one fetus in multifetal pregnancies. Fetal Diag Therap. 1996;11(5):366-72.

9. Gall SA. Multiple pregnancy and delivery. MosbyYear Book, IC.1996;199-222.

10. GABBE S.G., NIEBYL,J.R., SIMPSON J.L., OBS Normal and problem Pregnancies IV edition. Churchil Livingstone Publishes USA,2002.

11. Yasmeen N, Aleem M, Iqbal N. Maternal and fetal complications in multiple pregnancies. Ann $\mathrm{K} \mathrm{Ed}$ Med Coll. 2006;12:512-4.

12. Chittacharoen A. Pregnancy outcome of twin pregnancy in Ramathibodi Hospital. J Med Assoc Thai. 2006;89:576-80.

13. Khan H, saeeda M, Hafizulla M. Peculiar risk factors and complications of pregnancy induced hypertension in a tertiary care hospital of Peshawar. Pak Armed Forces Med J. 2009;4:9.

14. Rao A, Sairam S, Shehata H. obstetric complications of twin pregnancies. Best Pract Res Clin Obstet Gynaecol. 2004;18:557-76.

15. Khaliq S, Qureshi S, Roohi M. Multiple pregnancy: frequency of maternal and fetal complications. Professional Med J. 2008;15:175-8.

Cite this article as: Saravanan S, Loganathan M. Perinatal outcome of multiple pregnancy. Int J Reprod Contracept Obstet Gynecol 2017;6:2226-30. 